\title{
FeTeMM Eğitimine Yönelik Etkinlik Uygulaması: Kuvvet ve Enerji Örneği ${ }^{*}$ İsrafil TOZLU**, Emine GÜLSEVEN***, Mustafa TÜYSÜZ****
}

Öz: Bu çalışmanın amacı; yedinci sınıf Fen Bilimleri dersi “Kuvvet ve Enerji” ünitesi kapsamında argümantasyon temelli Cunningham mühendislik tasarım süreci ile örnek bir FeTeMM etkinliğinin basamaklarını uygulamalı bir şekilde açıklamak olarak belirlenmiştir. Araştırma 2018-2019 eğitim-öğretim yılında Van iline bağlı bir ortaokulda yedinci sınıfta öğrenim gören 32 öğrenci (21 erkek- 11 kız) ile gerçekleştirilmiştir. Etkinliğin uygulanması dört ders saati sürmüştür. Bu etkinlikteki temel amaç, kazanımların günlük yaşam problemleri ile ilişkilendirip, senaryolaştırarak öğrencilerin konu kavramlarını etkin bir şekilde anlamalarını sağlamaktır. Etkinlikler bir senaryo ile başlayıp Cunningham mühendislik tasarım sürecine (sor, hayal et, planla, oluştur, geliştir) Toulmin'nin argümantasyon modeli bileşenleri (iddia, veri, gerekçe, destek, niteleyici ve çürütme) entegre edilerek uygulanmıştır. Yüzen Aracım etkinliği, bilim ve mühendislik uygulamalarının fen derslerinde kullanılmasının faydalı olduğunu gösteren bir örnektir. Bu etkinliği sınıflarında uygulayacak olan öğretmenler argümantasyon temelli mühendislik tasarım süreciyle öğrencilere problem çözümü için farklı disiplinlerin kavramlarını kullanarak bilimsel olarak anlamlı gerekçelerle yeni ürün oluşturmayı, oluşturdukları ürünleri test etmeyi deneyimlemelerini sağlayacaklardır. Bu durum onlarda ileriye dönük 21. yüzyılda bireylerden beklenen becerilerin gelişimine katkı sunacağı düşünülmektedir.

Anahtar Kelimeler: FeTeMM etkinlik, Mühendislik tasarım süreci, Argümantasyon, Fen eğitimi

\footnotetext{
* Bu çalışma Van Yüzüncü Yıl Üniversitesinde yapılan yüksek lisans tez çalışmasından türetilmiştir.

** Dr. Öğr. Üyesi, Van Yüzüncü Yıl Üniversitesi, Eğitim Fakültesi, Matematik ve Fen Bilimleri Eğitimi Bölümü, Fen Bilgisi Eğitimi Anabilim Dalı https://orcid.org/0000-0002-9402-2539 E-mail: israfiltozlu@yyu.edu.tr ***Yüksek Lisans Öğrencisi, Van Yüzüncü Yıl Üniversitesi, Eğitim Bilimleri Enstitüsü, Orcid No: 0000-00030946-2626. E-mail: minelvan65@gmail.com

**** Dr. Öğr. Üyesi, Van Yüzüncü Yıl Üniversitesi, Eğitim Fakültesi, Matematik ve Fen Bilimleri Eğitimi Bölümü, Fen Bilgisi Eğitimi Anabilim Dalı https://orcid.org/0000-0003-1277-6669 E-mail: mustafatuysuz@yyu.edu.tr
} 


\section{Activity Application for STEM Education: Sample of Force and Energy}

Abstract: The aim of this study; the Cunningham engineering design process based on the argumentation was determined as the implementation of an exemplary STEM activity in the scope of the "Force and Energy" unit of the seventh grade science course The study was conducted with 32 students (21 boys-11 girls) in 7th grade in an elementary school in Van province in the 2018-2019 academic year. The implementation of the activity lasted 4 hours. The primary purpose of this activity is to make the students understand the concepts of the subject effectively by associating the related objectives of the topic with the problems of daily life and creating scenarios. The activities were implemented by starting with a scenario and integrating Toulmin's argumentation model components (claim, data, warrant, backing, qualifier, and refutation) into the Cunningham engineering design process (ask, imagine, plan, create, and improve). The Floating Vehicle activity is an example of the usefulness of science and engineering applications in science classes. Teachers, who will apply this activity in their classrooms, will provide students with the experience of creating a new product with scientifically meaningful reasons by using the concepts of different disciplines for solving of the problem with the help of the design process of engineering based on the argumentation. This situation is thought to contribute to the development of skills expected from individuals in the 21st century.

Keywords: STEM activity, Engineering design process, Argumentation, Science education

\section{Giriş}

Bilgi ve inovasyon çağı olarak adlandırılan içinde bulunduğumuz yüzyıl gelişen teknolojinin sayesinde bilgiye ulaşabilmeyi oldukça kolaylaştırmıştır. Ulaşılan yeni bilgiler bilişim çağını ortaya çıkararak bireylere yeni sorumluluklar kazandırmayı hedeflemiştir (Aydeniz, 2017). Bu yüzyılda her meslek dalında inanılmaz hızda gelişmeler meydana gelmektedir. Bireylerin bu gelişmelere uyum sağlayarak geleceğe katkıda bulunabilmeleri için, 21. yüzyıl becerileriyle yetişmiş olması zorunlu hale gelmektedir (Çınar, Pırasa ve Sadoğlu, 2016). Bu bağlamda içinde bulunduğumuz çağda bireylerden araştıran, sorgulayan, üretebilen, eleştiren ve analitik düşünebilen gibi becerilere sahip olması beklenmektedir (Partnership for 
21st Century Skills, 2009). Bahsi geçen hedeflerin gerçekleştirilmesi için ilk ve orta dereceli eğitim kurumlarında farklı ve yeni programların uygulanmasına ihtiyaç vardır. Özellikle ortaokul kurumlarındaki bireylerin her konuda olgunlaşmaya başlaması, toplumdaki yerini yavaş yavaş keşfetmesi, sorumluluklarını kazanabilmeleri açısından programlar oldukça önem taşımaktadır (Kavak ve Özdemir, 2007).

Ortaokul öğrencilerinden birçok disiplinde olduğu gibi fen bilimleri disiplininde de öncelikli olarak istenen; bireyin, toplum ve çevre arasındaki etkileşimin farkına varması, birey olarak ekonomiye, doğal kaynakların kullanılmasına ve sürdürülebilir kalkınmaya katkı sağlama bilincini geliştirmesidir (Şahin, Ayar ve Adıgüzel, 2014). Bu bağlamda öğrencilerin istenilen durumları gerçekleştirmeleri için araştırma-sorgulama yapabilmesi, farklı disiplinlerden yararlanarak argümanlar oluşturabilmesi ve bu argümanlardan hareketle kendi iddialarını oluşturup zıt olanları da çürütebilmeleri gerekir (Milli Eğitim Bakanlığı, 2013; Hasançebi, 2014). Birey doğduğu andan itibaren düşünür ve düşüncelerinden yola çıkarak argümanlar oluşturur. Oluşturdukları argümanları etrafındakilerle karşılaştırır ve kendi argümanlarının olumlu ve olumsuz yönlerini kolaylıkla farkına varır (Kaya \& Kılıç, 2008). Alan yazında argüman "bir konunun veya bir durumun ana yönlerini vurgulayarak ortaya çıkarıp, diğer bireyleri buna ikna etmek için ileri sürülen ifadelerdir” şeklinde tanımlanmaktadır (Güzel, Erduran ve Ardaç, 2009, s.34). Argümantasyon ise "bir tartışmanın içeriğinde yer alan iddia, veri, gerekçe, destek ve çürütme gibi öğelerin bir araya gelme sürecidir” olarak ifade edilmektedir (Simon, Erduran ve Osborne, 2006, s.14). Argümantasyon ilk olarak Toulmin tarafından 1958 yılında ileri sürülmüş ve “iddiaların veriler ışı̆̆ında gerekçelendirilmesi” olarak ifade edilmiştir (Binkley, 1995, s. 128). Ayrıca Argümantasyon uygulamalarını "bireylerde akıl yürütme ve tartışma becerilerinin gelişmesi “ şeklinde açıklamıştır (Demirel, 2015, s.71). 


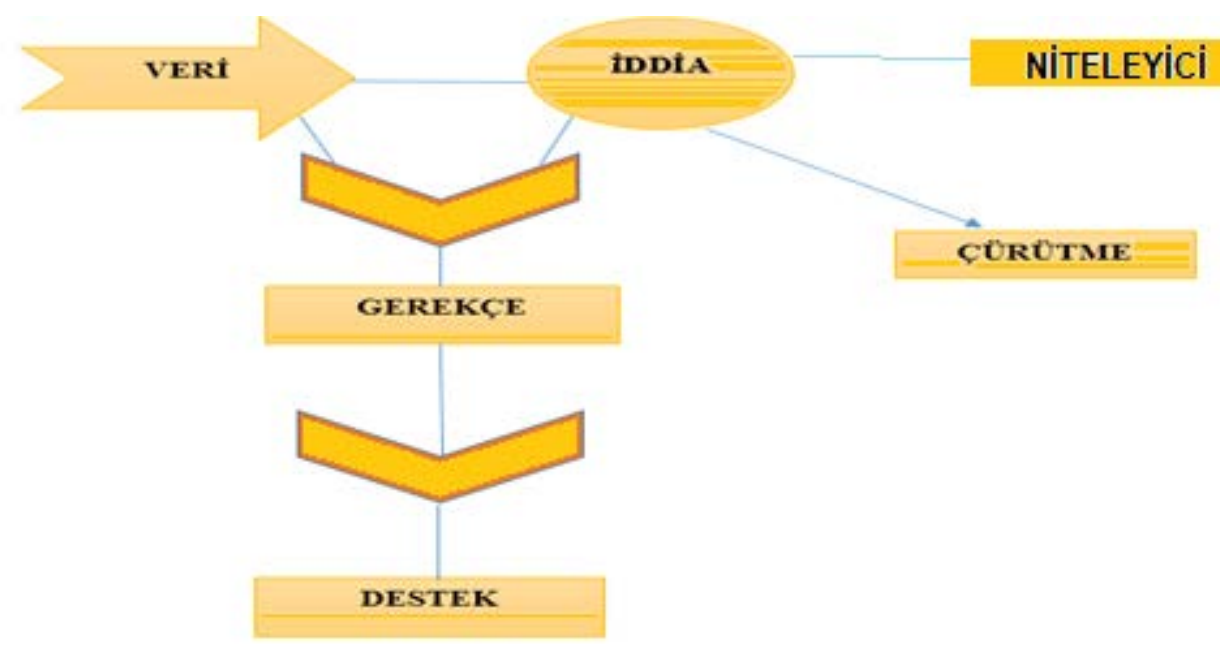

Şekil 1.Toulmin Argüman Modeli (Simon vd., 2006)

Toulmin modeline göre iddia, bir problemin çözümü için ileri sürülen ifadelerdir. Veri, iddiayı desteklemek için edinilen gözlemler ve toplanan bilgilerdir. Toplanan bilgilerin iddiayı hangi yönden desteklediğini gözler önüne seren veriler ise gerekçe olarak ifade edilir. Gerekçenin doğruluğunu arttıran örnekler ise destek olarak nitelendirilir. Bununla birlikte, Niteleyici/sınırlayıcı oluşturulan iddianın hangi koşullarda geçerli olduğunu belirtilirken, iddianın kabul edilmediği durumlarda geçersizliği çürütme ile ispatlanmaya çalışılır (Tümay ve Köseoğlu, 2011). Model, öğrencilerin görüş ve inançlarını dil aracılığıyla daha da güçlendirerek, bunları gözden geçirmelerini sağlamanın yanı sıra, akıl yürütürken ihtimallerin oynadığı rolü gösterip, aralarındaki argüman bağlantılarını ortaya çıkararak, argüman maharetlerinin geliştirilmesini desteklemektedir (Toulmin, 1958; Akt: Aydın ve Kaptan, 2014).

Argümantasyon bu yönleriyle 21. yüzyıl becerilerine sahip olan bireyler yetiştirmek için önemli bir unsurdur. Çünkü fen sınıflarında argümantasyon odaklı öğretim yaklaşımının kullanımı öğrencilerde bulunması gereken yaratıcılık, inovasyon, analitik ve eleştirel düşünme, girişimcilik ve problem çözme gibi becerilerin oluşmasını büyük ölçüde etkiler (Thomas, 2014). Argümantasyon, öğrencilerin öğrenilenleri içselleştirebilmesi için uygun öğretim yöntemi ile fen derslerinde kullanması gereken bir istişare şeklidir (Jimenez, Aleixander ve Erduran, 2007). Alan yazına bakıldığında ulusal ve uluslararası alanda argümantasyon yöntemini esas alan ve öğrenme çıktıları üzerine etkisini değerlendiren çalışmaların yapıldığı görülmektedir. Örneğin; Hand, Wallace ve Prain (2003), yapmış oldukları çalışmada, öğretmenlerin argümantasyon tabanlı öğrenme uygulamalarını gerçekleştirme becerisi ile 
öğrencilerin öğrenme çıktıları arasındaki ilişkiyi araştırmışlardır. Çalışmanın sonucunda öğretmenlerin bilgi kuramına yönelik inançlarının, değerlerinin ve uygulamalarının argümantasyonu uygulama becerilerine etki ettiği görülmüştür. Ayrıca çalışmadan elde edilen sonuçlar, argümantasyon tabanlı öğrenme ortamlarında öğrencilerin dilsel pratiklerinin ve bilimsel okuryazarlıklarının geliştiğini ortaya koymuştur. Venville ve Dawson (2010), çalışmalarında, onuncu sınıf öğrencilerinde argümantasyon oluşturma, akıl yürütme becerisi ve alan bilgisi değişkenleri arasında organik bir bağ olup olmadığını araştırmıştır. Çalışmanın sonucu deney grubunda yer alan bireylerin ürettiği argümantasyon sürecinin kalitesi, karşılaştırma grubuna göre anlamlı bir biçimde arttığını ortaya koymuştur. Başka bir çalışmada ise "Hücre Bölünmesi ve Kalıtım” ünitesinin öğretiminde argümantasyon temelli öğrenme sürecinin sekizinci sınıf öğrencilerinin akademik başarılarına, bilimsel bilginin doğasıyla ilgili anlayışlarına, tartışmaya katılma istekliliklerine ve Fen ve Teknoloji dersine yönelik tutumlarına etkisini incelemeyi amaçlamıştır. Çalışmanın sonucu, argümantasyon temelli öğrenme sürecinin öğrencilerin akademik başarılarını, tartışmalara katılma isteklerini artırdığını ayrıca fen dersine karşı olumlu tutumlar geliştirmelerine neden olduğunu ortaya koymuştur (Balc1, 2015). Yapılan çalışmalar incelendiğinde argümantasyon temelli eğitimin öğrencilerin bilişsel ve duyuşsal özelliklerine olumlu yönde katkı sağladığı görülmekte ve öğrencilerden beklenen 21. yüzyıl becerilerinin gelişimi için eğitimin her kademesine entegre edilmesi gerektiği düşünülmektedir.

Eğitim ve öğretim programları hazırlanırken temel amaçlardan biri, bireyleri yaşadıkları dünya için hazırlamak olmalıdır. Eğitim öğretim süreçleri boyunca bireylere gerçek yaşam problemlerini doğru tespit edip bu problemlere işbirliği içerisinde çözüm yolları üretebilme becerileri kazandırılmalıdır. Bu nedenle programlar geliştirilirken tasarım sürecine gereken önem verilerek bilgilerin pratikte uygulanabilir olmasına önem verilmelidir (Güzey, Harwell ve Moore, 2014). Eğitimin tasarım boyutuna ve somut bir yapıya dönüştürülmesine öncelik veren eğitim modelleri, bireylerin teorik bilgiler ile gerçek yaşam arasında ilişki kurmalarına, çözüm yolları üretmelerine ve geleceklerini şekillendirmede yardımcı olacaktır (Yı1maz, 2012; Gülgün, 2014). Günümüz eğitimcileri, bireylerin geleceği daha iyi şekillendirebilmeleri için ilk olarak üretken olmaları paydasında birleşmektedirler (MEB, 2016). Bu bağlamda eğitim sistemimizin dünya ile yarışabilmesi, bireylerin bilimsel okuryazar, başarılı bir sanayi ve üretim merkezleri inşa edebilmesi için eğitim programlarımıza kavramlar ve disiplinler arası ilişkilerin eklenmesi bireylerin geleceğe katkıda bulunmasının önünü açacaktır. 
Ortaokul öğretim programlarına bakıldığında fen ve matematik dersleri ayrı dersler olarak bulunmalarına rağmen birbiriyle bağlantılı disiplinlerdir. Bu disiplinlerde teknoloji kısmı zaman zaman yer alsa da mühendislik alanına genellikle değinilmediği ortaya çıkmaktadır (Bozkurt-Altan, Yamak, Buluş-Kırıkkaya, 2016; Öner ve Capraro, 2016; Temel, 2012). Öte yandan mühendisliğin, fen, matematik ve teknoloji eğitiminde edinilen kuramsal bilgilere uygulama olanağı sağlayacağı ve somut ürünler ortaya çıkaracağı düşüncesi ile mühendisliğinde diğer disiplinler gibi okullarda işlenmesini gerekli kılmıştır. Özellikle fen eğitiminde Fen'in, Teknoloji, Matematik ve Mühendislik disiplinleriyle ilişkilendirilmesi bu alanda büyük bir adım olacaktır. Bu dört temel disiplinin bütün bir şekilde verilmesine STEM (Science, Technology, Engineering, Mathematics; Türkçe kısaltması: FeTeMM eğitimi denilmektedir (Yıldırım ve Altun, 2015). Son yıllarda gelişmiş ülkelerin başta ABD olmak üzere eğitim politikalarına bakıldığında FeTeMM kısaltmasının geniş bir yer kapladığını görmekteyiz. ABD Eğitim Bakanlığı'na göre, dünyada en hızlı gelişim gösteren iş alanlarının \%75'nin bilim veya matematik eğitimi gerektirdiği ve bu sebepten ötürü öğrencilerin üniversite sonrası iyi bir iş istihdamı için donanımlı FeTeMM bilgisine sahip olmaları gerektiği görülmektedir (Becker ve Park, 2011).

Ülkemizde de çok popüler hale gelen ve hızlı bir gelişim gösteren FeTeMM eğitimi farklı disiplinleri bir arada entegre bir şekilde kullanılmasıyla dünya üzerinde en ses getiren değişimlerden birisidir. FeTeMM eğitiminin amacı fen, teknoloji, mühendislik ve matematik disiplinlerini entegre bir şekilde vererek öğrencilerin gerçek yaşam problemleri arasında ilişki kurarak, bu problemleri yaratıcılıklarını kullanarak çözmelerini sağlamaktır (Yamak, Bulut \& Dündar, 2014). Öğrencilerin doğru çözümlere ulaşabilmesi için bu disiplinler açıklayıcı ve birbirini destekleyici şekilde tasarlanmıştır. Birçok öğrenci için mühendislik ve teknoloji disiplinleri, fen ve matematik disiplinleri için uygulama imkânı sağlamaktadır (Banks ve Barlex, 2014). Bunun yanı sıra FeTeMM eğitimi, aktif öğrenmeyi, bilgiyi transfer edebilmeyi, problemlere bütüncül bir bakış açısıyla bakmayı, eleştirel ve sistemli düşünmeyi, problem çözmeyi gibi bilgi ve becerilerinin yanında yaratıcılık, bilgi ve medya okuryazarlığı, işbirliği ve özgüven gibi 21. yüzyıl becerilerinin geliştirilmesini hedeflemektedir. Bununla birlikte Fen Bilimleri ve Matematik gibi dersleri ezber sisteminden çıkartıp, öğrencilerin Fen, Teknoloji, Mühendislik ve Matematik, disiplinlerinde uzmanlaşmalarına da olanak tanıyarak bireylerin yeni ürünler ortaya koymalarını sağlamaktadır (Şahin, Ayar ve Adıgüzel, 2014; Yıldırım ve 
Altun, 2015). Bu bağlamda FeTeMM temelinde geliştirilen eğitimler bireylerde ihtiyaç olan meslekleri seçiminde öncülük edecektir.

Ülkemizde bireylerde yenilikçi ve inovatif düşüncülerin arttırılması ayrıca yaşam standartlarının geliştirilmesi için küçük yaşlardan itibaren FeTeMM merkezli öğrenme ortamları oluşturulmalıdır (Çorlu, Capraro ve Capraro, 2014). Eğitim sistemimizde 2017 yılında taslak olarak hazırlanan öğretim programı 2018 yılında ortaokulun tüm kademelerinde uygulamaya konulmuştur. Öğretim programının içeriğine bakıldığında çeşitli yeniliklerin yapıldığı görülmektedir. Bu yenilikler; "Mühendislik ve Tasarım” becerileri ve "Fen, Mühendislik ve Girişimcilik Uygulamaları” olarak görülmektedir. Bu yenilikler incelendiğinde FeTeMM yaklaşımını oluşturan öğelerle ilişkili olduğu ve teknoloji boyutuna da vurgular yapıldığı görülmektedir (Bahar, Yener, Yılmaz, Emen ve Gürer, 2018; Özbilen, 2018; Tekbıyık ve Çakmakçı, 2019). Alan yazında yer alan çalışmalar incelendiğinde yenilenen 2017 öğretim programından önce uygulanan programlarda daha çok geleneksel öğretimin uygulandığı, öğrencilerin bir disiplinde kazandıkları bilgi ve becerileri diğer disiplinlere transfer edemedikleri görülmektedir (Çavaş, 2002; Özdemir, 2006; Karaca, 2010). Geleneksel öğretim yöntemi aktarma ve aktarılanı direk alma üzerine yoğunlaşır. Bu öğretim anlayışı, öğrencileri ezbere yönelterek hazıra alıştırır. Öğrencinin merak duygusunu köreltir ve sorgulamayan dolayısıyla üretmeyen bireylerin oluşmasına sebep olur. Dersler disipliner yapıda ve birbirinden bağımsız olarak oluşturulur. Derslerin haftalık uygulanma süreleri önceden belirlenir ve öğretmeninde bu sürelere paralel ders işlenmesi beklenir. Değerlendirme aşamasında öğretmenlerin daha az zaman ve daha az enerji harcadıkları, öğrencilerin sadece alınan bilgileri yorum katmadan direk geri ileteceği değerlendirme ölçütleri (kısa cevaplı, boşluk doldurma, doğru-yanlış, çoktan seçmeli ve eşleştirme vb.) kullanılır (Bayraktar, 1998; Teo ve Ke, 2014 ). Geleneksel öğretim anlayışıyla hazırlanmış ders kitabı etkinlikleri incelendiğinde, etkinliklerin daha çok alıştırma şeklinde hazırlandığı görülmektedir. Alıştırma daha çok aktarılan konuları pekiştirir ve alışkanlık oluşturur yani daha çok öğretim için kullanılır. Öğrenci sadece tekrar yapar, ezberlediklerini hatırlar, kendisi konuyu içselleştirmez, üzerine hiçbir katkıda bulunmaz (Güneş, 2017). Ancak fen öğretiminde öğrenme ve öğretme sürecinde teknoloji, mühendislik ve matematik gibi farklı disiplinlerin birbiriyle bağlantılı bir şekilde kullanımının öğrenmeler üzerinde etkili olduğu, bunun yanı sıra mühendislik ve teknoloji uygulamalarının fen bilimleri öğretimini desteklediği söylenmektedir (Ceylan, 2014; Yıldırım, 2016; Çiftçi, 2018). Bu bağlamda geleneksel öğretime uygun olarak tasarlanan öğretim programları FeTeMM eğitim 
ortamı için uygun olmamakla beraber öğrencilerde FeTeMM alanlarına karşı ön yarg1 ve ilgisizliği artırmıştır (Roberts, 2012). Bu problemle karşılaşmamak ya da olası durumları ortadan kaldırmak için FeTeMM eğitimini en iyi şekilde uygulamak ve ulaşılmak istenen hedefleri gerçekleştirmek için öğrenme ortamlarında FeTeMM entegrasyonu yapılmalıdır. Alan yazın incelendiğinde bu nokta ile ilgili olarak; içerik ve bağlam entegrasyonu olmak üzere iki farklı yordamdan bahsedilmektedir (Roehrig, Moore, Wang ve Park, 2012). İçerik entegrasyonu; içerik alanlarının tek bir müfredat faaliyetinde birleştirilmesine ve bu alandaki bir problemi çözmek için disiplinlerin tümünün kullanılmasına odaklanır. Bir öğretmenin her disiplinden içerik öğretmesine ve bunların nasıl olduğunu vurgulamasına izin verir. Bağlam entegrasyonunda ise; temel olarak bir disiplinin içeriğine odaklanılır ve diğer disiplinleri içeriği daha anlaşılır hale getirmek için kullanılır. Bu entegresyonda FeTeMM disiplinleri bir ünite ve ya bir konuda bütünleştirilir (Roehring vd. 2012). Bu çalışmanın hedefine ulaşması için başvurulan yaklaşım bağlam entegrasyonu olarak ele alınmıştır. Çalışmanın esas amacı fen bilimleri konu alanı olmasına rağmen mühendislik tasarım süreci ve teknoloji alanları entegre edilerek konu ile ilgili kavramlarının daha iyi anlaşılması ve benimsenmesi için kullanılmaktadır. Bu çalışmada FeTeMM disiplinlerinin entegrasyonu mühendislik tasarım süreçleri çerçevesinde gerçekleştirilmektedir (Daugherty, 2013). Bu yönüyle alan yazın çalışmaları incelendiğinde, mühendislik tasarım sürecini yapılandırmak için birbirinden farklı basamaklandırılmış modeller bulunmaktadır. Bu çalışmada Cunningham tarafından 2009'da ortaya konulan ve beş basamaktan oluşan, katılımcı öğrencilere sorular sorarak sürece rehberlik eden model temel alınmıştır. Modeldeki basamaklar şu şekildedir.

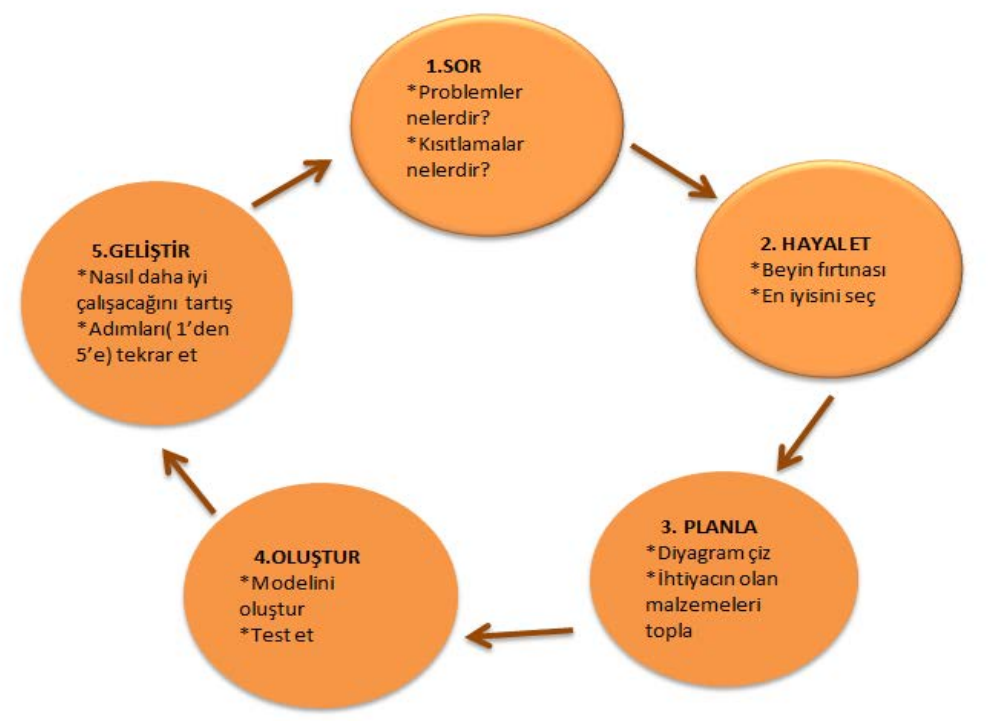




\section{Şekil 2. Cunningham Mühendislik Tasarım Süreci}

1.Sor: Bu basamakta problem tanımlanır. Problem durumuyla ve problemin çözümüne yönelik alternatif yöntemlerin bulunması için uygun sorular sorulur. Oluşturulan tasarı için olası engeller ( materyal eksikliği vb.) belirlenir. Öğrencilerin önceki bilgileriyle konu ilişkilendirilir. 2.Hayal Et: Bu basamakta beyin firtınası yapılarak, olası çözüm önerileri üretilir. Üretilen düşünceler yazıya ya da resme dökülür.

3.Planla: Bu basamakta üretilen düşünceler için uygulama yöntemi seçilir. Seçilen bu yöntem şema haline getirilir. Koşullar belirlenerek gerekli materyaller tedarik edilir.

4.Yarat: Bu basamakta plan uygulamaya konulur ve tasarı oluşturulur. Tasarı oluşturulduktan sonra test edilir.

5.Geliştir: $\mathrm{Bu}$ basamakta tasarıyı daha iyi bir hale getirebilmek için yeni fikirler üretilir. Üretilen bu fikirler doğrultusunda tasarı geliştirilerek basamaklar doğrultusunda yeniden test edilir (Gülhan, 2016).

Günümüzde fen eğitiminin tek bir öğretim yöntemiyle verilmesinin yeterli olmadığı ve diğer disiplinlerle ilişkilendirilerek verilmesinin gerekliliği eğitimciler tarafından kabul edilmektedir. FeTeMM entegralinde; araştırmacıların hem etkinlik geliştirmede hem de ders planı hazırlamada birbirinden farklı öğretim yöntemleri kullandıkları görülmektedir. FeTeMM eğitiminde; Yaratıcı drama, 5E öğrenme modeli, proje tabanlı öğrenme, tam öğrenme modeli gibi farklı metotlar ile birlikte kullanıldığı da görülmektedir (Capraro, Capraro ve Morgan, 2013; Dass, 2015; Han, Capraro ve Capraro, 2015; Özsoy, 2017; Y1ldırım ve Selvi 2017 ). Yine FeTeMM eğitiminin entegre edildiği yaklaşımlardan biri de Argümantasyon' dur. Argümantasyon yaklaşımında öğrenciler günlük yaşamda karşılaştıkları problemleri iddia, tartışma ve kanıtları kullanarak FeTeMM eğitimindeki mühendislik tasarım sürecine entegre ederek çözebilecekleri düşünülmektedir (Çorlu, 2014; Demircioğlu ve Uçar, 2014; Fairweather, 2008). Fakat FeTeMM ve argümantasyon yönteminin birlikte kullanıldığı çalışmaların nadir olduğu görülmektedir. Bu bakımdan alan yazındaki bu boşluğa katkı sağlamak için FeTeMM eğitimi ve argümantasyon öğrenme yönteminin birlikte yapılacağı bu çalışma ayrıca önem arz etmektedir. Bir ülkedeki bilimin ve ekonominin temelden gelişmesi FeTeMM eğitimine gereken önemin verilmesi ile mümkündür (Lacey ve Wright, 2009; Şahin, Ayar ve Adıgüzel 2014). FeTeMM ülkemizde henüz yeni bir yaklaşım olduğundan dolayı öğrencilerde bu temelin oluşturulabilmesi için etkili yöntemler kullanılmalıdır. $\mathrm{Bu}$ çalışma ile öğrenciler 
argümantasyon temelli hazırlanmış fen, teknoloji, matematik ve mühendislik (FeTeMM) disiplinlerini bir arada kullanan etkinlikler ile üst düzey beceriler elde edeceklerinin yanında kuşkusuz öğrenilen bilgilerin aktif katılım ile gerçekleşeceğinden dolayı daha kalıcı olacağı düşünülmektedir. Çünkü onlar bu çalışma ile öğrenecekleri farklı disiplinlerden kavramları günlük yaşama uyarlayabilecekleri bir tasarım sürecine aktif olarak katılacaklardır.

Ders kitapları öğretim programlarını somutlaştıran, öğrencilere bilgiler vererek onları araştırma ve sorgulama yapmaya yönlendiren, öğrenme ortamlarını düzenleyen araçlardır (K1lıç, 2005). Eğitim sürecinde belli dönemlerde programlar hazırlanır. Hazırlanan bu programlar eğitimciler tarafından uygulanır. Uygulama aşamasında temel rol oynayan faktör yine kitaplardır (Morgil ve Yılmaz, 1991). Fen bilimleri dersi bir bilim dersi olduğu için, fen bilimleri ders kitabı da öğrencilerin çok yönlü gelişimlerini destekler nitelikte ve bilgiyi somutlaştıran etkinlikler içermesi gerekir (Karamustafaoğlu, 2009). Ancak 2018 yılında uygulamaya konulan öğretim programının FeTeMM yaklaşımı ile birebir bağdaşık olduğu söylenemez. Özellikle ders kitaplarındaki etkinliklerin 21. yüzyıl becerileri içerme noktasında eksikliklere rastlanmıştır (Bahar, Yener, Yılmaz, Emen ve Gürer, 2018; Özbilen, 2018; Tekbıyık ve Çakmakçı, 2019; Tezcan, 2018). FeTeMM etkinlikleri 21. yy. becerileri (eleştirel düşünme, problem çözme, yaratıcılık, üretkenlik vb.) içermelidir. Bu etkinliklerin sonunda öğrencilerin bir ürün oluşturmaları gerekir (Morrison, 2013; Bybee 2010). Bu bağlamda ders kitaplarındaki yer alan etkinliklere bakıldığında süreç sonunda ürün oluşturmaya yönelten etkinliklerin yeterli düzeyde olmadığı görülmektedir (Tezcan, 2019). Bunun yanı sıra FeTeMM etkinlikleri sonunda ortaya çıkarılan ürünlerin öğrencilere özgü yani orijinal olması gerekir (Yamak, Bulut ve Dündar 2014; Yıldırım, 2018). FeTeMM eğitiminde kullanılan değerlendirme rubriklerinde tasarım süreci, tasarım sonucu, grup içi etkileşimi, hazırladı ̆̆ sunum ya da posterlerde değerlendirmeye alınarak puan verilir (Teo ve Ke, 2014). Fakat ders kitabındaki değerlendirme ölçütleri incelendiğinde FeTeMM etkinliklerini değerlendirmede yeterli olmadığı belirlenmiştir (Tezcan, 2019). Bu bağlamda öğretmenler için uygulayabilecekleri FeTeMM öğretim etkinliklerin gerek sayı bakımından yetersiz olması, gerekse de kitapta bulunan bazı etkinliklerin FeTeMM yaklaşımının temel özelliklerine sahip olmaması problem teşkil etmektedir. Bu çalışma ile tasarlanan örnek bir FeTeMM etkinliğinin basamaklarını uygulamalı bir şekilde açıklanması alan yazına katkı sağlayacağı düşünülmektedir. 
Fen konularını günlük hayat ile ilişkilendirerek fen eğitiminin kalitesini artırmak ve öğrencilerin derse ilgilerini devamlı hale getirmek için yeni öğretim materyallerinin kullanılması gerekir. Böylelikle bu çalışmanın amacı; yedinci sınıf fen bilimleri dersi "Kuvvet ve Enerji” ünitesi kapsamında argümantasyon temelli Cunningham mühendislik tasarım süreci ile tasarlanan örnek bir FeTeMM etkinliğinin uygulamalı bir şekilde açıklanması olarak belirlenmiştir.

\section{YÖNTEM}

Etkinliğin Uygulanması: Araştırma 2018-2019 eğitim-öğretim yılında Van iline bağlı bir ortaokulda yedinci sınıfta öğrenim gören 32 öğrenci $(21$ erkek- 11 k1z) ile gerçekleştirilmiştir. Uygulama yapılan öğrenciler akademik başarıları ve cinsiyetlerine göre heterojen gruplar oluşturacak şekilde birbirine denk altı grup şeklinde oluşturulmuş ve öğrencilerden kendi gruplarına isim vermeleri istenmiştir. Etkinliğin uygulanması dört ders saati sürmüştür. Etkinlik hazırlanmadan önce “Kuvvet ve Enerji” ünitesi ile ilgili Milli Eğitim Bakanlığının hazırlamış olduğu EBA internet sitesi, MEB'in uygulamaya koyduğu yedinci sınıf ders kitabı etkinlikleri, MORPA eğitim portalı ve farklı yayınlardaki fen bilimleri ders kitapları incelenerek FeTeMM entegrali yapılmış argümantasyon metinleri geliştirilmiştir. Etkinliğin öğretim yöntemine uygunluğu ve eğitsel yönden kazanımları karşılayıp karşılamadığı bir devlet üniversitesinde argümantasyon ve FeTeMM ile ilgili önemli çalışmaları olan iki öğretim üyesinin görüşüne başvurulmuştur. Yapılan bu etkinlik "Hava veya su direncinin etkisini azaltmaya yönelik bir araç tasarlar.” kazanımına yönelik hazırlanmıştır. Bu etkinlikteki temel amaç, kazanımların günlük yaşam problemleri ile ilişkilendirip, senaryolaştırarak öğrencilerin konu kavramlarını etkin bir şekilde anlamalarını sağlamaktır. Öğretim süreci öncesinde öğrencilere argümantasyon yöntemi ve mühendislik tasarım sürecinin uygulanış şekli ile ilgili bilgiler verilmiştir. Etkinlik bir senaryo ile başlayıp Cunningham mühendislik tasarım sürecine (sor, hayal et, planla, oluştur, geliştir) Toulmin'nin argümantasyon modeli bileşenleri (iddia, veri, gerekçe, destek, niteleyici ve çürütme) entegre edilerek uygulanmıştır. Argümantasyon yönteminin FeTeMM eğitiminde yer alan mühendislik tasarım sürecine entegresi Tablo-1'de verilmiştir. 
Tablo 1. Argümantasyon Yöntemi ve Mühendislik Tasarım Süreci Arasındaki İlişki

\begin{tabular}{l|l}
\hline Argümantasyon Yöntemi & Mühendislik Tasarımı \\
\hline Problemi belirle. & Problemi tanımla. \\
\hline $\begin{array}{l}\text { Gözlem yap ve toplanan bilgileri } \\
\text { değerlendirerek olası çözümleri seç. }\end{array}$ & $\begin{array}{l}\text { Cözümler bulmak için beyin fırtınası yap ve } \\
\text { uygun olanı seç. }\end{array}$ \\
\hline $\begin{array}{l}\text { Toplanan verileri problem durumuna göre } \\
\text { değerlendirerek en uygun olanını belirle. }\end{array}$ & $\begin{array}{l}\text { Bir prototip üret ve bunu test etmek için } \\
\text { materyaller topla. }\end{array}$ \\
\hline Gerekçeleri neticelendir ve test et. & Tasarımı sonuçlandır ve görselleştir. \\
\hline Sonuçları tartış ve yeniden değerlendir. & Tasarımını gözden geçir ve yeni fikirlerle \\
& tekrar test et. \\
\hline
\end{tabular}

\section{Etkinlik: Yüzen Aracım}

Yüzen aracım etkinliği, “7 7.3.3.2.Hava veya su direncinin etkisini azaltmaya yönelik bir araç tasarlar.” kazanımına yönelik tasarlanmıştır ve dört ders saati sürmüştür. Bu konu deniz ve hava ile ilgili ortamlardaki kuvvetleri, özellikle sürtünme kuvvetinin cisimler üzerindeki etkisi konusunda bilgi ve anlayışı geliştiren, Deniz, Hava ve Kara Mühendisliği ile ilişkili bir konudur. Derse giriş aşamasında öğrencilerin konuya ilgilerini yoğunlaştırmaları için bazı kara taşıtları ve hava taşıtları gösterilmiş ve araçların kullanım amaçları açıklanmıştır. Ayrıca öğrencileri konuya hazırlayıcı sorular da sorulmuştur. Daha sonra öğrenciler önceden belirlenen grup üyeleri ile bir araya gelerek etkinliklere başlanmıştır. İlk olarak gruplara etkinlik senaryoları dağıtılmıştır. Öğrencilere on dakikalık süre içinde senaryoları okuyup aralarında fikir alışverişinde bulunmaları istenmiştir.

1. Sor (20 dakika): Bu basamakta öğrenciler; senaryoda belirtilen probleme ve olası ortam koşullarına göre çözüm yolları bulmaya çalışmış, senaryo metinlerindeki "veri” bölümüne gruplar “ Sürtünme kuvveti bazı yerlerde fazladır. Asfaltta az olur araba hızlı gider ama toprak yolda çok olur araba yavaş gider.”, “ Yonca'nın yarışmada birinci olabilmesi için aracının çok hızlı gitmesi gerekir. Suda hızla gitmek zordur çünkü bir kuvvet uygular ve bizim bile yürümemizi zorlaştırır. Bu yüzden de Yonca aracını suda hızlı gidecek şekilde yapmalıdır.” gibi çözüm yolları için topladıkları ön bilgileri ve gözlemlerini yazmışlardır. Bu gözlemlerde öğrencilerin fen disiplinlerini kullandıkları görülmektedir. Daha sonra “iddia” bölümüne ise "Yarışmada birinci olmak için suyun 
sürtünme kuvvetini yenecek bir araç tasarlamalıyız", ”Yonca birinci olmak istiyorsa hem hava direncini hem de su direncini azaltmaya yarayacak bir araç tasarlamalıdır." gibi tüm verileri grup arkadaşları ile müzakere ederek problem durumunu en iyi ifade eden iddia cümleleri yazmışlardır. Araştırmacı öğrencilerin ilgi ve motivasyonlarını daha çok artırmak ve uygun hipotezi oluşturmalarına yardımcı olmak için öğrencilerine pek çok soru yöneltmiştir. Bu sorular "Tasarlayacağınız araç için hangi bilgilere ihtiyacınız var?”, "Bu araç nasıl daha hızlı gidebilir?”, “Aracın boyutu hızını nasıl etkiler?”, "Araç olumsuz hava koşullarında nasıl önlem almalıdır?”, “Aracın amaca hizmet etmesi için hangi malzemeleri kullanırsınız?" gibi düşünmeye sevk eden sorulardan oluşmaktadır. Böylece öğrenciler sorulara vermiş oldukları cevapları derleyerek iddialarını oluşturmuşlardır. Bu iddialarını oluştururken hem fen, matematik, teknoloji ve mühendislik disiplinlerini birbirleriyle entegre ederek kullanmaları sağlanmıştır.

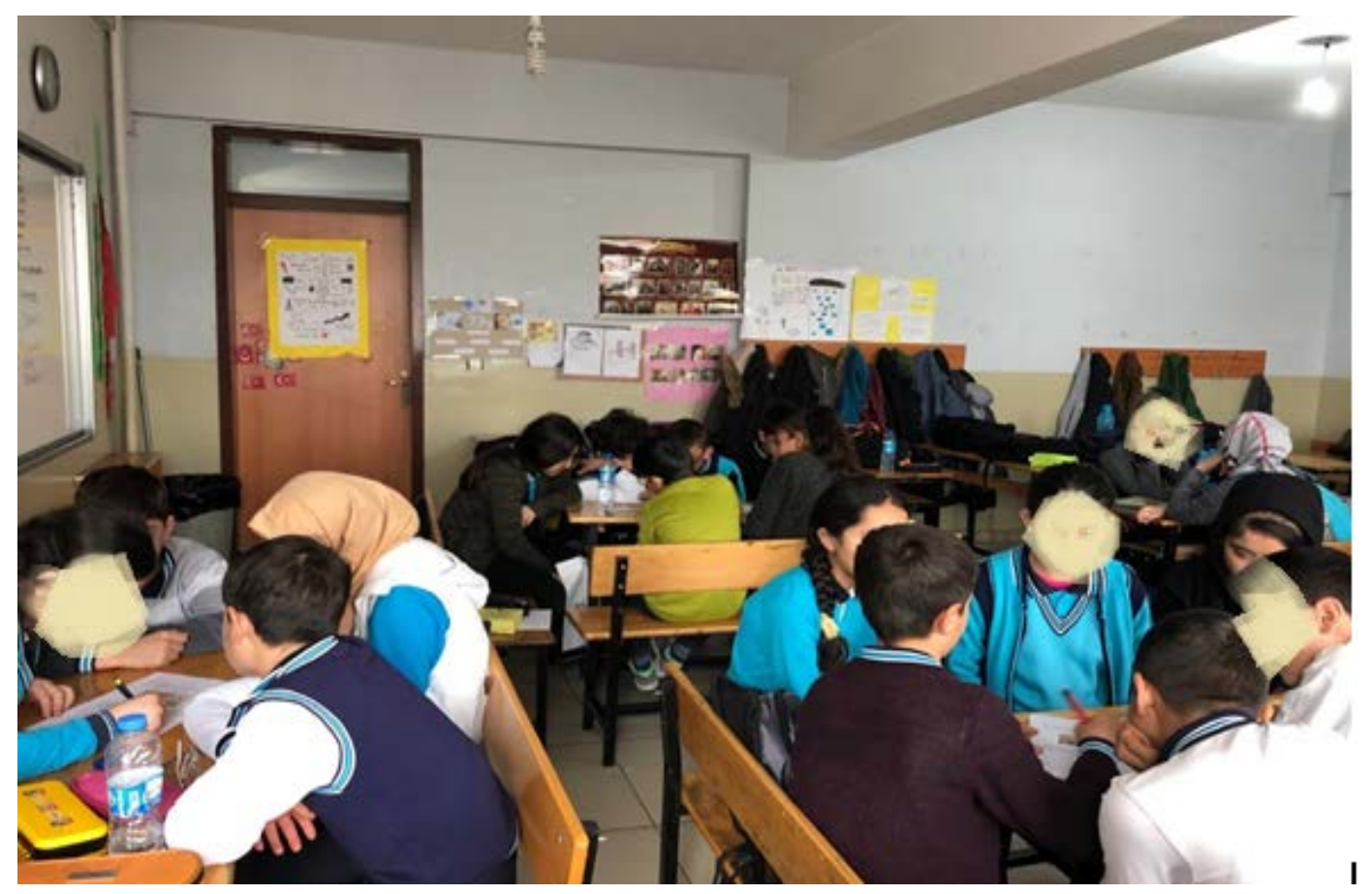

Fotoğraf 1. Öğrencilerin senaryo metinlerini değerlendirmeleri ve grup içi müzakereleri

2. Hayal Et (20 dakika): Bu basamakta öğrenciler hem öğretmen hem de kendi aralarında beyin fırtınası yaparak topladıkları tüm verileri değerlendirerek önceki aşamada belirlenen problem durumlarına yönelik "gerekçe” bölümüne “ Su direnci azaldı̆̆ında araç daha hızlı gider.”, 
“Ali havanın sürtünme kuvvetini yenecek şekilde bir uçurtma yapmıştır ve birinci olmuştur. Bizde aynı şeyi suda denemeliyiz.” gibi olası çözüm yollarını yazmışlardır. Bunun için olabildiğince farklı çözüm önerilerini derleyip hayal ederek çözüm için yazılan gerekçeleri çizim yaparak desteklemişlerdir. Gerekçeleri yazarken daha çok fen, mühendislik ve matematik disiplinlerini entegre ederek kullandıkları görülmektedir.

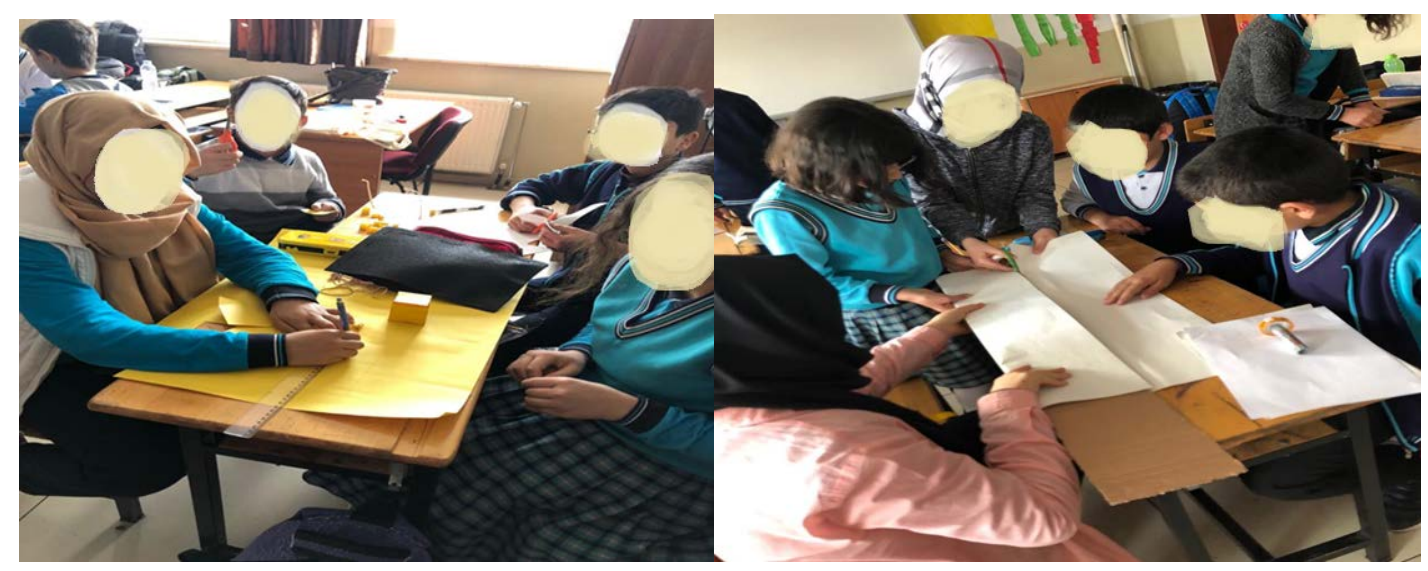

Fotoğraf 2. Öğrencilerin çözüm yollarını çizimlerle desteklemeleri

3. Planla (20 dakika): Bu aşamada öğrenciler yazmış oldukları gerekçeleri problem durumunu göz önünde bulundurarak gözden geçirmişlerdir. "Destek” bölümüne “Gemiler tasarlanırken genellikle su direncini azaltacak şekilde tasarlanır.", "Aracın çok hızlı gitmesi için sürtünmeyi yenmeli, bu yüzden aracına ' $V$ ' burun yapmalı ve rüzgârın yönünde gitmelidir." gibi olası durumları yazarak gerekçelerini neticelendirerek en uygun uygulama yöntemini belirlemişlerdir. Daha sonra seçilen yöntemi uygulamaya koymak için olası durumları belirleyerek çözüm yolunda kullanacakları, onlara daha önce verilen kriterlere göre (tehlike içermeyen, maliyeti düşük kolay temin edilebilen) basit araç, gereçleri tedarik etmişlerdir. $\mathrm{Bu}$ tasarlamalarda fen, mühendislik, matematik ve teknoloji disiplinlerini bir arada kullandıkları görülmektedir. 


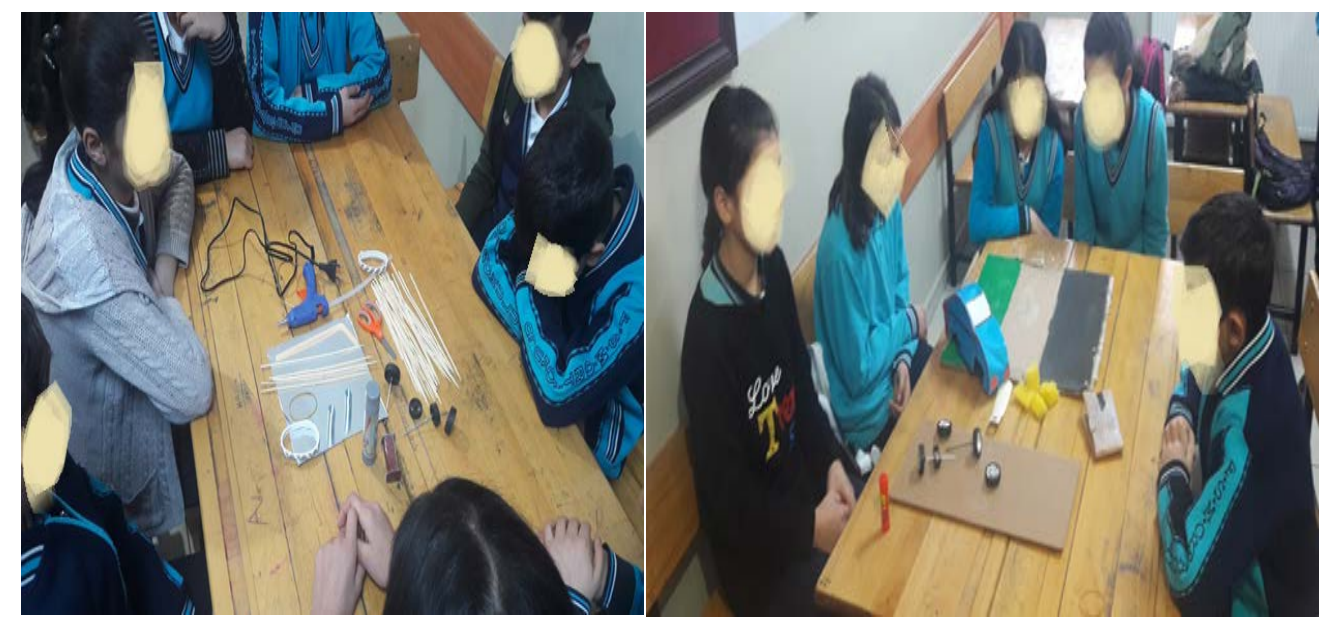

Fotoğraf 3. Öğrencilerin oluşturacakları ürünler için hazırlamış oldukları malzemeler

4. Oluştur (40 dakika): Bu aşamada öğrenciler ilk aşamada oluşturdukları iddialarına yani problem durumlarına yönelik belirlemiş oldukları çözümü el becerilerini kullanarak ürün oluşturmuşlardır. Öğretmen ise öğrencilere tehlike arz edecek araçları (makas, bıçak vb.) kullanırken yardımcı olmuştur. Ayrıca gruplar arasında dolaşarak öğrencilerin tasarlama süreci dışına çıkmamalarını ve el becerileri gerektiren durumlarda öğrencilerin başarılı olabilmesi ve pes etmemesi için onları cesaretlendirmiştir. $\mathrm{Bu}$ aşamanın sonucunda öğrenciler ortaya çıkardıkları ürünün çalışıp çalışmadığını ve daha önce belirlenen kriterlere uygun olup olmadığını test etmişlerdir. Son olarak gruplar tasarladıkları ürünleri sınıfta sunmuşlardır.
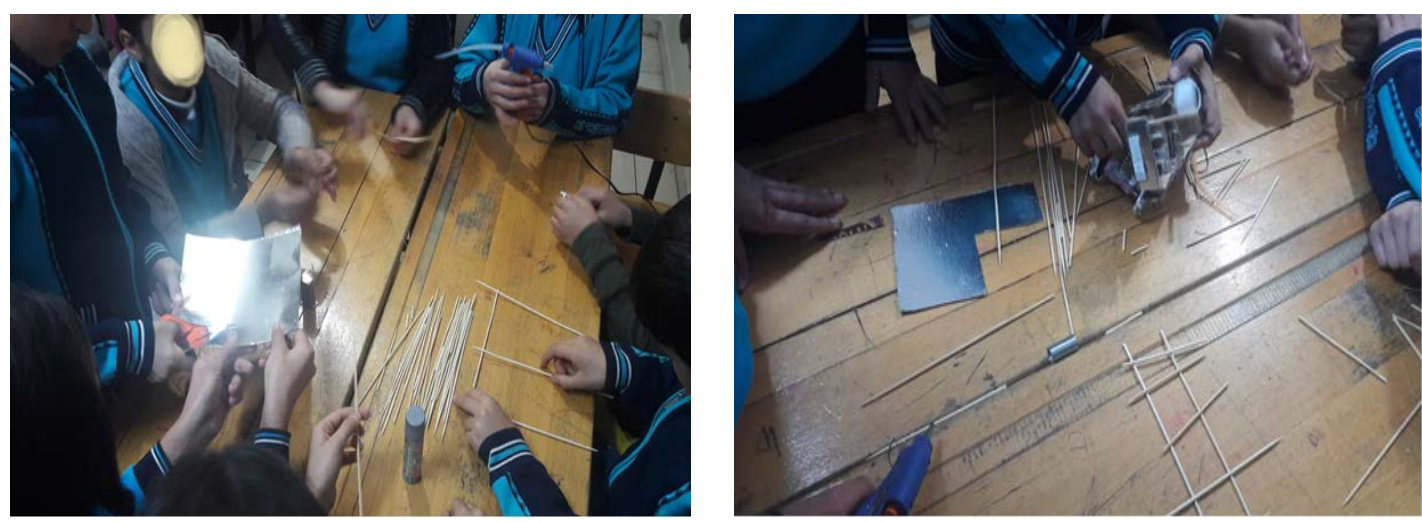

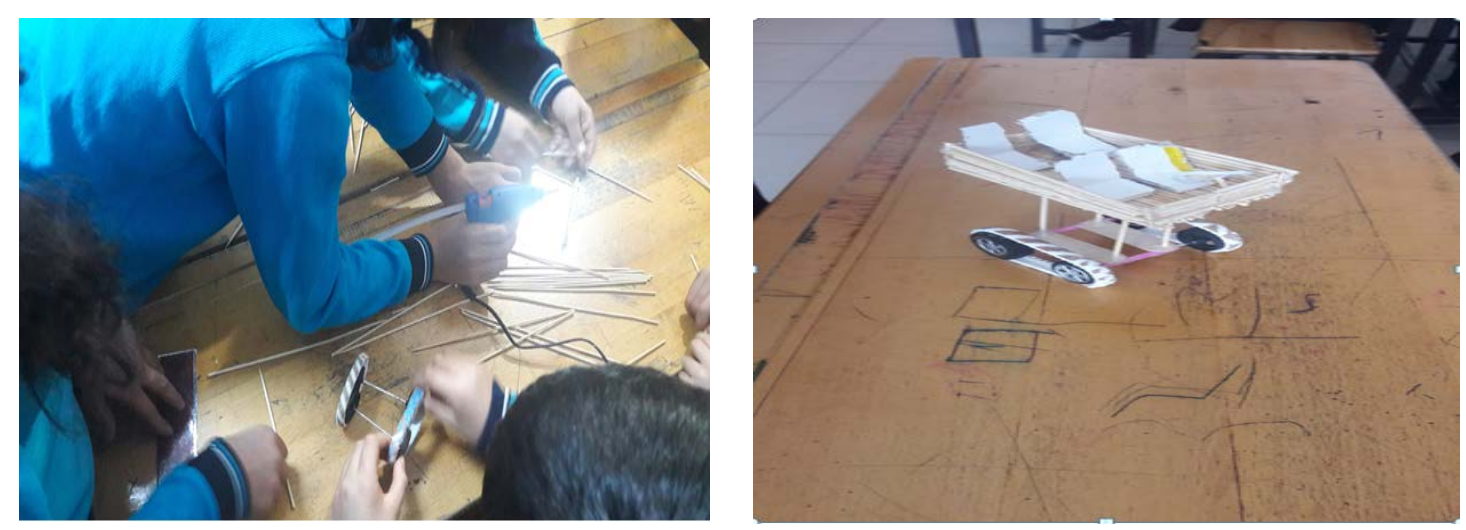

Fotoğraf 4. Öğrencilerin yüzen araba ürünlerinin tasarımı ve test edilmesi

5. Geliştir (40 dakika): Bu aşamada gruplar önceki aşamada oluşturmuş oldukları ürünleri test ettikten sonra tasarımlarının daha önce verilen kriterlere uygun olup olmadığını diğer gruplarla ile tartışma ortamı oluşturularak değerlendirmeleri sağlanmıştır. Bu tartışmaların verimli olabilmesi için öğretmen demokratik bir ortamın oluşması için rehberlik etmiştir. Tartışmalar daha çok ürünlerin varsa eksik yönleri veya çalışma durumlarının iyileştirilmesi için yapılmıştır. Örneğin, değerlendirmeler sonucunda "Tasarlanan araçlar belki de dalga yönünde gittikleri için ilerlemişlerdir.”, “Aracın önü kare olmalıdır, 'V' şeklinde olursa hızlandığında duramaz." "Çürütme" olabilecek durumları yazarak her grup kendi tasarımlarını yeniden gözden geçirmiş ve eksik kısımlar iyileştirildikten sonra ürünlerini tekrar test etmişlerdir.
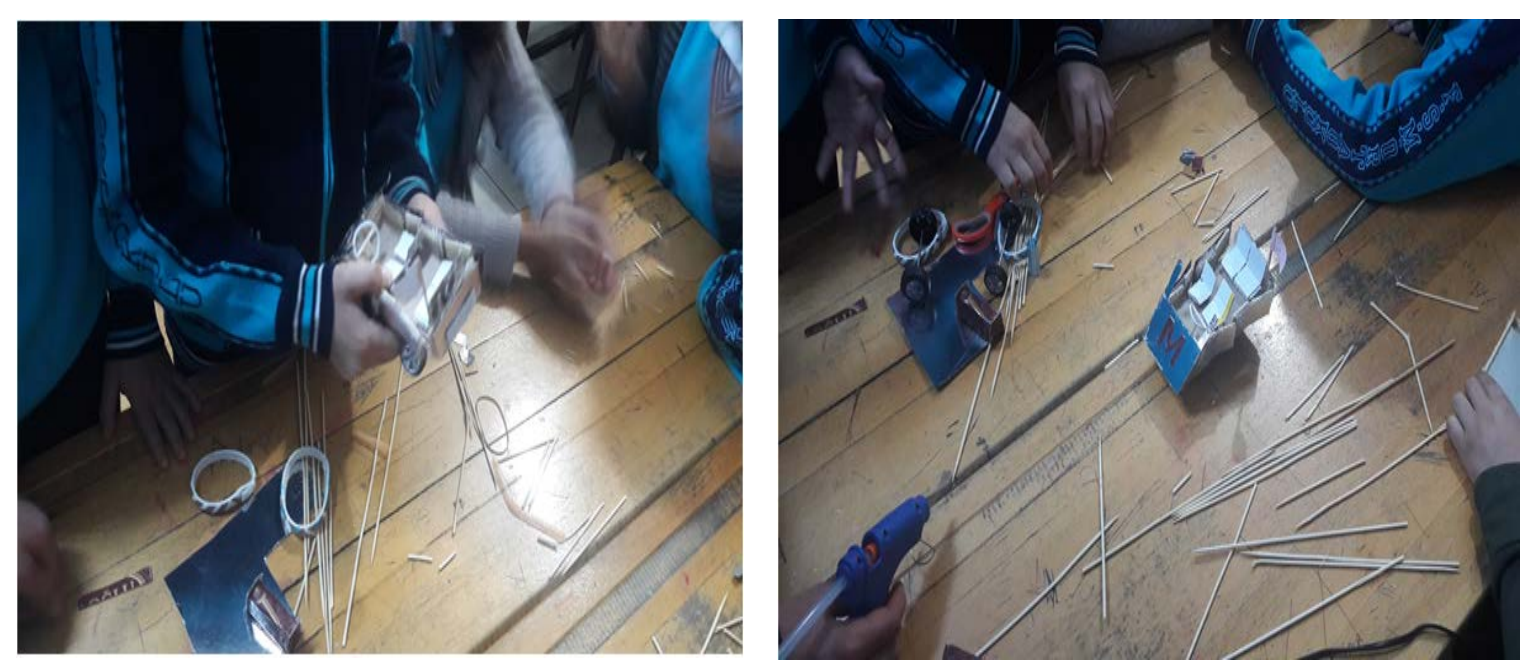

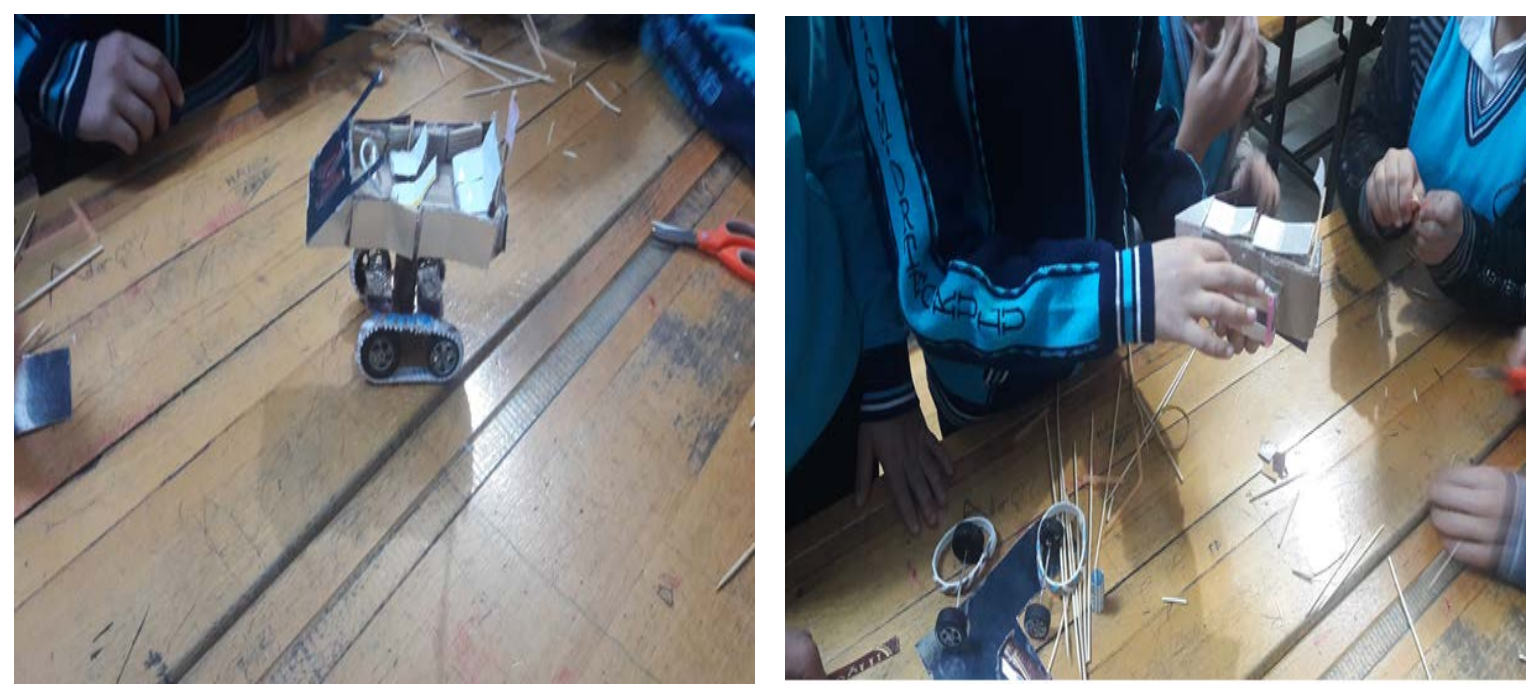

Fotoğraf 5. Öğrencilerin tasarımlarını iyileştirmeleri ve tekrar test etmeleri

\section{Sonuç ve Öneriler}

Günümüzde eğitimde çağdaş öğretim teknolojilerinin kullanıldığı su götürmez bir gerçektir. Fakat teknolojik gelişmeler hangi boyutta olursa olsun gerek ülkeler, gerek bölgeler gerekse de yöreler arasında hatta aynı yörede farklı okullar arasında bile öğretim materyalleri konusunda bir standarttın olmadığı, bunlara ulaşmada da zorlukların olduğu görülmektedir. $\mathrm{Bu}$ gibi durumlarda fen bilimleri öğretmenleri bazı materyalleri hazırlayabilir ya da öğrencilere rehberlik ederek onların kendi materyallerini hazırlamalarını sağlayabilir. Yüzen Aracım etkinliği, bilim ve mühendislik uygulamalarının fen derslerinde kullanılmasının faydalı olduğunu gösteren bir örnek olduğu düşünülmektedir. Bu etkinliği sınıflarında uygulayacak olan öğretmenler argümantasyon temelli mühendislik tasarım süreci ile belirlenen problem çözümü için farklı disiplinlerin kavramlarını kullanarak bilimsel olarak anlamlı gerekçelerle yeni ürün oluşturma, oluşturdukları ürünleri test etme deneyimlemelerini sağlayacaklardır. $\mathrm{Bu}$ durum onlarda ileriye dönük 21. yüzyılda bireylerden beklenen becerilerin gelişimine katk1 sunacağı düşülmektedir. Uygulamaya katılan öğrenciler uygulama sırasında öğretmenlerine etkinliklerin zevkli ve daha akılda kalıcı olduklarını dile getirmişlerdir. Etkinliklerde kullandıkları malzemelerin temin edilmesinin ekonomik ve ulaşılabilirliğin kolay olduğunu belirtmişlerdir. Ayrıca, etkinliğin çok masraflı olmaması ve bütün okullarda rahatlıkla uygulanabilir olması da yine avantajları arasında belirtilmiştir. $\mathrm{Bu}$ durum alan yazında tasarlanan örnek FeTeMM etkinliklerinde de görülmektedir. Örneğin, Aydın-Günbatar (2018) Wheeler ve diğerleri (2014) mühendislik modeli basamaklarını kullanarak tasarlamış olduğu 
elmanın kararmasının engellenmesine yönelik bir FeTeMM etkinliğinde uygulayıcı öğretmenler öğrencilerin etkinliğe zevkle katıldıklarını ve süreç içerisinde kolay ulaşılabilir malzemelerle farklı düşünceler ile ürün tasarımları gerçekleştirmişlerdir.

Ayrıca uygulamanın argümantasyon yöntemiyle gerçekleştirilmesi süreç sırasında öğrenciler arasında işbirliğini ve problem durumlarına karşı ortak paydada buluşabilmeyi pekiştirmiştir. Öğrenciler etkinliklerin sonunda fotoğraflardan da görüldüğü üzere orijinal ve amaca hizmet eden ürünler ortaya çıkartarak ilgili kavramları farklı disiplinlerle entegre ederek anlamlı bir şekilde öğrenmelerine katkı sağladığı düşünülmektedir. Öğretmen süreç sonunda öğrencilere etkinlikler ile ilgili görüşlerini sorduğunda öğrencilerin büyük bir kısmının etkinlikleri başka konularda da yapmak istediklerini söylediklerini belirtmiştir. Alan yazında argümantasyon odaklı öğretim etkinliklerinin öğretim ortamlarında kullanılmasının öğrencilerin kavramsal anlamalarını da güçlendirdiği ortaya konmuştur (Aymen-Peker, Apaydın ve Taş, 2012; Büber, 2015; Driver, Newton ve Osborne, 2000; Erduran ve JiménezAleixandre, 2007; Hand, 2008; Türkoğuz ve Çin, 2013; Üstünkaya ve Gencer, 2012). Örneğin, Aktaş (2017) yapmış olduğu çalışmada “Kuvvet ve Enerji” ünitesinin öğretiminde “Argümana Dayalı Sorgulama" yönteminin yedinci sınıf öğrencilerinin akademik başarılarına, tartışmaya katılma isteklerine ve argümantasyon seviyelerine etkisini incelemeyi amaçlamıştır. Çalışmanın sonucu “Argümana Dayalı Sorgulama” modelini temel alan laboratuvar yönteminin deney grubu öğrencilerinin akademik başarılarına önemli düzeyde etki ettiğini ancak tartışmaya katılma isteklerine geleneksel laboratuvar yöntemine göre anlamlı düzeyde etki etmediğini ortaya koymuştur.

$\mathrm{Bu}$ çalışma sadece yedinci sınıf kuvvet ve enerji ünitesi kapsamında argümantasyon yöntemi entegre edilerek yapılmıştır, dolayısıyla araştırmacılar farklı sınıf düzeyleri ile farklı ünitelerde ve farklı öğretim yöntemleri entegre ederek uygulayabilirler. Hazırlanan etkinlik fen dersi ile ilgili hazırlanmıştır bu nedenle farklı disiplinlerde de kullanılabilir.

\section{Makalenin Bilimdeki Konumu}

Matematik ve Fen Bilimleri Eğitimi, Fen Bilgisi Eğitimi Anabilim Dalı

\section{Makalenin Bilimdeki Özgünlüğü}

$\mathrm{Bu}$ makale son yıllarda oldukça yaygın konulardan biri olan FeTeMM eğitimi ile bireylerin herhangi bir konuda ispat ve dayanaklandırmalarla bir fikri veya bir hipotezi 
açıklama ve savunma gibi sınıf içinde sosyal etkileşimlerin artmasını sağlayan argümantasyon sürecinin bütünleştirildiği metinlerin sınıf içindeki uygulama şeklini gösteren özgün bir çalışmadır.

\section{Kaynakça}

Aktaş, T.(2017). Argümana Dayalı Sorgulama Öğretiminin 7. Sınıf Öğrencilerinin Kuvvet ve Enerji Ünitesindeki Akademik Başarılarına ve Argümantasyon Seviyelerine Etkisi. (Yayınlanmamış yüksek lisans tezi), Marmara Üniversitesi, Eğitim Bilimleri Enstitüsü, İstanbul.

Aydeniz, M. (2017). Eğitim sistemimiz ve 21. Yüzy1l hayalimiz: 2045 hedeflerine ilerlerken, Türkiye için STEM odaklı ekonomik bir yol haritası. http://trace.tennessee.edu/utk_theopubs/ 17 adresinden erişildi.

Aydın, Ö., ve Kaptan, F. (2014). Fen-Teknoloji öğretmen adaylarının eğitiminde argümantasyonun biliş üstü ve mantıksal düşünme becerilerine etkisi ve argümantasyona ilişkin görüşler. Eğitim Bilimleri Araştırmaları Dergisi, 4(2), 163188.

Aydın-Günbatar, S. (2018). Designing a process to prevent apple’s browning: A STEM activity. Journal of Inquiry Based Activities (JIBA)/Araştırma Temelli Etkinlik Dergisi (ATED), 8(2), 99-110.

Aymen-Peker, E., Apaydın, Z., ve Taş, E. (2012). Isı yalıtımını argümantasyonla anlama: ilköğretim 6. sınıf öğrencileriyle durum çalışması. Dicle Üniversitesi Sosyal Bilimler Enstitüsü Dergisi, 4(8): 79-100.

Bahar, M., Yener, D., Y1lmaz, M., Hayrettin, E. M. E. N., ve Gürer, F. (2018). 2018 fen bilimleri öğretim programı kazanımlarındaki değişimler ve fen teknoloji matematik mühendislik (STEM) entegrasyonu. Abant İzzet Baysal Üniversitesi Eğitim Fakültesi Dergisi, 18(2), 702-735.

Balcı, C. (2015). 8. Sınıf Öğrencilerine "Hücre Bölünmesi Ve Kalıtım" Ünitesinin Öğretilmesinde Bilimsel Argümantasyon Temelli Öğrenme Sürecinin Etkisi. (Yayımlanmamış Yüksek Lisans Tezi). Adnan Menderes Üniversitesi, Fen Bilimleri Enstitüsü, Aydın.

Banks, F., and Barlex, D. (2014). Teaching STEM in the secondary school: Helping teachers meet the challenge. London: Routledge. 
Bayraktar, E. (1998). Bilgisayar destekli matematik öğretimi. (Yayınlanmış doktora tezi, Ankara Üniversitesi, Sosyal Bilimler Enstitüsü, Ankara.

Becker, K., and Kyungsuk, P. (2011). Effects of integrative approaches among science, technology, engineering, and mathematics (STEM) subjects on students’ learning: A preliminary meta-analysis. Journal of STEM Education: Innovations and Research,12(5/6), 23-37.

Binkley, R. W. (1995). Argumentation, education and reasoning. Informal Logic, 17(2), 127143.

Bozkurt-Altan, E., Yamak, H., ve Buluş-Kırıkkaya, E. B. (2016). Hizmetöncesi öğretmen eğitiminde FeTeMM eğitimi uygulamaları: Tasarım temelli fen eğitimi. Trakya Üniversitesi Eğitim Fakültesi Dergisi, 6(2), 212-232.

Buber, M. (2015). Eclipse of God: Studies in the relation between religion and philosophy. PRINCETON; OXFORD: Princeton University Press. Retrieved from http://www.jstor.org/stable/j.ctvc777pc

Bybee, R. W. (2010). Advancing STEM education: A 2020 vision. Technology and Engineering Teacher, 70(1), 30-35.

Capraro, R. M., Capraro, M. M., and Morgan, J. R. (Eds.). (2013). STEM project-based learning: An integrated science, technology, engineering, and mathematics (STEM) approach. Rotterdam, The Netherlands: Sense Publishers.

Ceylan, S. (2014). Ortaokul Fen Bilimleri Dersindeki Asitler Ve Bazlar Konusunda Fen, Teknoloji, Mühendislik Ve Matematik (FeTeMM) Yaklaşımı İle Öğretim Tasarımı Hazırlanmasına Yönelik Bir Çalışma. (Yayımlanmamış yüksek lisans tezi). Uludağ Üniversitesi, Eğitim Bilimleri Enstitüsü, Bursa.

Cunningham, C. M. (2009). Engineering is elementary. The Bridge, 30(3), 11-17.

Çavaş, B. (2002). İlköğretim 6. Ve 7. Sınıflarda Okutulan Matematiğe Dayalı Fen Konularında Yaşanan Sorunlar, Matematiğin Bu Sorunlar İçerisindeki Yeri Ve Bu Sorunların Giderilmesinde Teknolojinin Rolü Ve Çözüm Önerileri. (Yayımlanmamış yüksek lisans tezi). Dokuz Eylül Üniversitesi, Eğitim Bilimleri Enstitüsü, İzmir.

Çınar, S., Pırasa, N., and Sadoğlu, G. P. (2016). Views of science and mathematics preservice Teachers Regarding STEM. Universal Journal of Educational Research, 4(6), 1479-1487. 
Çiftçi, M. (2018). Geliştirilen STEM Etkinliklerinin Ortaokul Öğrencilerinin Bilimsel Yaratıcılık Düzeylerine, STEM Disiplinlerini Anlamalarına Ve STEM Mesleklerini Fark Etmelerine Etkisi. (Yayınlanmamış yüksek lisans tezi) Recep Tayyip Erdoğan Üniversitesi, Eğitim Bilimleri Enstitüsü, Rize.

Çorlu, M. S. (2014). FeTeMM eğitimi makale çağrı mektubu. Turkish Journal of Education, 3(1), 4-10.

Çorlu, M. S., Capraro, R. M. and Capraro, M. M. (2014). Introducing STEM education: implications for educating our teachers for the age of innovation. Eğitim ve Bilim, 39(171), 74-85.

Dass, P.M. (2015). Teaching STEM effectively with the learning cycle approach. K12 STEM Education, 1(1), 5-12.

Daugherty, M. K. (2013). The prospect of an “A” in STEM education. Journal of STEM Education, 14(2), 10-15.

Demircioğlu, T. ve Uçar, S. (2014). Akkuyu nükleer santrali konusunda üretilen yazılı argümanların incelenmesi. İlkögretim Online, 13(4),1373-1386

Demirel, R. (2015). Katı basıncı konusunda argümantasyon etkinliğinin uygulanmast. Journal of Inquiry Based Activities, 5(2), 70-90.

Driver, R., Newton, P., and Osborne J. (2000). Establishing the norms of scientific argumentation in classrooms. Science. Education, 84(3), 287-312. DOI: 10.1002/(SICI)1098-237X(200005)84:3<287::AID-SCE1>3.0.CO;2-A.

Erduran, S., and Jiménez-Aleixandre, M. P. (2007). Argumentation in science education: Recent developments and future directions. Dordrech: Springer.

Fairweather, J. (2008). Linking evidence and promising practices in science, technology, engineering, and mathematics (STEM) undergraduate education. Board of Science Education, National Research Council, The National Academies, Washington, DC.

Han, S., Capraro, R. and Capraro, M. M., 2015. How science, technology, engineering, and mathematics (STEM) project-based learning (PBL) affects high, middle, and low achievers differently: The impact of student factors on achievement. International Journal of Science and Mathematics Education, 13(5) 1089-1113

Hand, B., Wallace, C., and Prain, V. (2003, August). Teacher issues in using a science writing heuristic to promote science literacy in secondary science. 4th European Science Education Research Association Conference, Noordwijkerhout, The Netherlands. 
Hand, B. (2008). Science inquiry, argument and language: A case for the science writing heuristic. Rotterdam, The Netherlands: Sense Publishers.

Hasançebi, F. (2014). Argümantasyon tabanlı bilim öğrenme yaklaşımının (ATBÖ) öğrencilerin fen başarıları, argüman oluşturma becerileri ve bireysel gelişimleri üzerine etkisi. (Yayınlanmamış Doktora Tezi). Atatürk Üniversitesi, Erzurum.

Guzey, S.S., Harwell, M., \& Moore, T. (2014). Development an instrument to assess attitudes toward science, technology, engineering, and mathematics (STEM). School Science and Mathematics, 114(6), 271-279.

Gülgün, C. (2014). Sınıf Öğretmenlerinin Fen Öğretimine Yönelik Tutumları İle Öğrencilerinin Fen Başarıları Arasındaki İlişkinin Araştırılması (Sivas). (Yayınlanmamış yüksek lisans tezi) Kastamonu Üniversitesi Eğitim Bilimleri Enstitüsü, Kastamonu.

Gülhan, F. (2016). Fen-teknoloji-mühendislik-matematik entegrasyonunun (STEM) 5. sinıf öğrencilerinin algı, tutum, kavramsal anlama ve bilimsel yaratıcılıklarına etkisi. (Yayımlanmamış doktora tezi). Marmara Üniversitesi, İstanbul.

Güneş, F. (2017). Türkçe öğretimi yaklaşımlar ve modeller. Ankara: Pegem Akademi Yayınc1lık.

Güzel, B. Y., Erduran, S., ve Ardaç, D. (2009). Aday kimya öğretmenlerinin kimya derslerinde bilimsel tartışma (argümantasyon) tekniğini kullanımları. Boğaziçi Üniversitesi Eğitim Dergisi, 26(2), 33-48.

Jiménez-Aleixandre, M. P., \& Erduran, S. (2007). Argumentation in science education: An overview. In Argumentation in science education (pp. 3-27). Springer Netherlands

Karaca, N. (2010). Bilgisayar Destekli Animasyonların Grafik Çizme Ve Yorumlama Becerisinin Geliştirilmesine Etkisi: "Yaşamımızdaki Sürat Örneği”. (Yayımlanmamış yüksek lisans tezi ).Karadeniz Teknik Üniversitesi, Eğitim Bilimleri Enstitüsü, Trabzon.

Karamustafaoğlu, O. (2009). Fen ve teknoloji eğitiminde temel yönelimler. Kastamonu Ĕgitim Dergisi, 17(1), 87-102

Kavak, Y., ve Özdemir, S. (2007). Türkiye'de ilköğretim ve geleceğe baklş. Türkiye'de okulöncesi ĕgitim ve ilkögretim sistemi, temel sorunlar ve çözüm önerileri. Ankara: Türk Eğitim Derneği. 
Kaya, O.N. ve Kılıç, Z. (2008). Etkin bir fen öğretimi için tartışmacı söylev. Ahi Evran Üniversitesi Kırşehir Eğitim Fakültesi Dergisi, 9, 89-100.

Kılıç, D. (2005). Ders kitabının öğretimdeki yeri. Ö.Demirel ve K. Kıroğlu (Ed.), Konu alanı ders kitabı incelemesi içinde ( s.37-53 .). Ankara: Pegem A Yayıncılık.

Lacey, T. A., and Wright, B. (2009). Employment outlook: 2008-18-occupational employment projections to 2018. Monthly Labor Review., 132, 82.

MEB.(2013) . İlköğretim Kurumları (İlkokullar Ve Ortaokullar) Fen Bilimleri Dersi (3, 4, 5, 6, 7 ve 8. Sinıflar) Öğretim Programı, Ankara.

Milli Eğitim Bakanlığı -MEB- (2016). STEM eğitimi raporu. Ankara: Milli Eğitim Bakanlığ1 Yayinlar.

Morgil, F.i., ve Yılmaz, A., (1991). Lise X. sınıf, kimya II ders kitaplarının öğretmen ve öğrenci görüşleri açısından değerlendirilmesi. Balıkesir Üniversitesi Fen Bilimleri Enstitüsü Dergisi, 1(1), 26-41.

Morrison, J. (2013). TIES STEM education monograph series, attributes of STEM education. Baltimore: MD TIES.

Öner, A. T., and Capraro, R. M. (2016). Is STEM academy designation synonymous with higher student achievement?. Education \& Science/Egitim ve Bilim, 41(185), 1-17. DOI: 10.15390/EB.2016.3397.

Özbilen, A. G. (2018). Stem eğitimine yönelik öğretmen görüşleri ve farkındalıkları. Scientific Educational Studies, 2(1), 1-21.

Özdemir, N. (2006). İlköğretim 2. Kademedeki Fen Bilgisi Öğretiminde Yaşanan Sorunlar Ve Çözüm Önerileri. (Yayımlanmamış yüksek lisans tezi). Pamukkale Üniversitesi, Eğitim Bilimleri Enstitüsü, Denizli.

Özsoy, S. (2017). Is the earth flat or round? Primary school children's understandings of the planet earth: The case of Turkish children. International Electronic Journal of Elementary Education, 4(2), 407-415.

Partnership for 21st Century Skills-P21. (2009). P21 framework definitions. Retrieved from 26.01.2019tarihinde[Çevirimiçi:http://www.p21.org/storage/documents/P21_Frame work_Definitions.pdf ], Erişim tarihi: 28.09.2018.

Roehrig, G. H., Moore, T. J., Wang, H. H., and Park, M. S. (2012). Is adding the E enough? Investigating the impact of K-12 engineering standards on the implementation of STEM integration. School Science and Mathematics, 112(1), 31-44. 
Roberts, A. (2012). A justification for STEM education. The Technology and Engineering Teacher, 71(8), 15. Retrieved from: http://www.iteaconnect.org/mbrsonly/Library/TTT/TTTe/04-12roberts.pdf.

Simon, S., Erduran, S., and Osborne, J. (2006). Learning to teach argumentation: Research and development in the science classroom. International Journal of Science Education, 28(2-3), 235-260.

Şahin, A., Ayar, M.C., ve Adıgüzel, T. (2014). Fen, Teknoloji, Mühendislik ve Matematik içerikli okul sonrası etkinlikler ve öğrenciler üzerindeki etkileri. Educational Sciences: Theory \& Practice, 14(1). DOI: 10.12738/estp.2014.1.18763.

Tekbıyık, A. ve Çakmakçı, G.( 2018). Fen bilimleri öğretimi ve STEM etkinlikleri kitabı. Ankara: Nobel Yayınları.

Temel, H., (2012). İlköğretim 4-8 Fen Ve Teknoloji Ve Matematik Öğretim Programlarının Fen Ve Matematik Entegrasyonuna Göre İncelenmesi. (Yayınlanmamış yüksek lisans tezi) Abant İzzet Baysal Üniversitesi, Eğitim Bilimleri Enstitüsü, Bolu.

Teo, T. W., and Ke, K. J. (2014). Challenges in STEM teaching: Implication for preservice and inservice teacher education program. Theory Into Practice, 53(1), 18-24.

Tezcan, G. (2019). Ortaokul Fen Bilimleri Ders Kitaplarında Yer Alan Etkinliklerin Bilim, Teknoloji, Mühendislik Ve Matematik Yaklaşımına Uygunluğunun İncelenmesi Ve Öğretmen Görüşleri. (Yayınlanmamış yüksek lisans tezi). Van Yüzüncü Y1l Üniversitesi, Eğitim Bilimleri Enstitüsü, Van.

Thomas, T.A. (2014). Elementary teachers"e receptivity to integrated science, technology, engineering, and mathematics (STEM) education in the elementary grades. (Unpublished Phd Thesis) University of Nevada, Nevada.

Toulmin, S. (1958). The uses of argument. Cambridge, UK: Cambridge University Press.

Tümay, H., ve Köseoğlu, F. (2011). Kimya öğretmen adaylarının argümantasyon odaklı öğretim konusunda anlayışlarının geliştirilmesi. Türk Fen Eğitimi Dergisi, 8(3), 105119.

Türkoğuz, S., ve Merve, C. İ. N. (2013). Argümantasyona Dayalı Kavram Karikatürü Etkinliklerinin Öğrencilerin Kavramsal Anlama Düzeylerine Etkisi. Dokuz Eylül Üniversitesi Buca Ĕ̌itim Fakültesi Dergisi, (35), 155-173.

Üstünkaya ve Gencer (2012, Haziran), İlköğretim 6.sınıf Seviyesinde Bilimsel Tartışma (Argumentatıon) Odaklı Etkinliklerle Dolaşım Sistemi Konusunun Öğretiminin 
Akademik Başarıya Etkisi, X. Ulusal Fen Bilimleri ve Matematik Eğitimi Kongresi, 27-30. Niğde.

Venville, G. J. and Dawson, V. M. (2010). The impact of A classroom intervention on grade 10 students' argumentation skills, informal reasoning, and conceptual understanding of science. Journal of Research in Science Teaching, 47(8): 952-97.

Yamak, H., Bulut, N., ve Dündar, S. (2014). 5. sınıf öğrencilerinin bilimsel süreç becerileri ile fene karşı tutumlarına FeTeMM etkinliklerinin etkisi. Gazi Eğitim Fakültesi Dergisi, 34(2), 249-265.

Yıldırım, B., ve Altun, Y. (2015). STEM eğitim ve mühendislik uygulamalarının fen bilgisi laboratuvar dersindeki etkilerinin incelenmesi. El-Cezeri Journal of Science and Engineering, 2(2), 28-40.

Y1ldırım, B. (2016). An analyses and meta-synthesis of research on STEM education. Journal of Educational and Practice, 33(7), 23-33.

Yıldırım, B., ve Selvi, M. (2017). STEM uygulamaları ve tam ögrenmenin etkileri üzerine deneysel bir çalışma. Eğitimde Kuram ve Uygulama, 13(2), 183-210.

Yıldırım, B. (2018). Teoriden pratiğe STEM eğitimi uygulama kitabı. Ankara: Nobel Yayınları.

Yılmaz, A. (2012). İlköğretim 8. Sınıf Öğrencilerinin Fen Ve Teknoloji Dersine Karş1 Tutumlarının Fen Ve Teknoloji Dersini Günlük Hayatla İlişkilendirebilmedeki Başarılarına Etkisi. (Yayınlanmamış yüksek lisans tezi) Gazi Üniversitesi. Eğitim Bilimleri Enstitüsü, Ankara. 


\section{Summary}

Problem Statement: One of the main objectives in forming education and training programs should be to prepare individuals for the world in which they live. For this purpose, individuals should be able to identify the real-life problems correctly and produce the solutions to these problems in cooperation throughout the education and training process. Training models that give priority to transforming education into a design dimension and a concrete structure will help to establish a relationship between theoretical knowledge and real life, find solutions, and shaping the future (Y1lmaz, 2012; Gulgun, 2014). In this context, the inclusion of interdisciplinary relations in educational programs should be necessary to our education system to compete with the world, for individuals to build a scientific literate, successful industry, and production centers. When elementary school curriculum is evaluated, it is seen that although the technology is partly involved, the engineering field is often not integrated (Bozkurt-Altan, Yamak, Bulus-Kırıkkaya, 2016; Öner and Capraro, 2016; Temel, 2012). However, it was stated that the interrelated use of different disciplines such as technology, engineering, and mathematics in science teaching has a positive impact on the learning (Ceylan, 2014; Y1ldırım, 2016; Ciftci, 2018). STEM education should be integrated into learning environments to achieve the goals. The integration of the disciplines of STEM is carried out within the framework of engineering design processes (Daugherty, 2013). In this respect, when literature is examined, there are different models for structuring the engineering design process. In this study, Cunningham introduced an engineering model consisting of five steps in 2009. In addition, it is seen that researchers use different teaching methods in both developing activities and preparing lesson plans for STEM integration. One of these teaching approaches is Argumentation. It is thought that students will be able to solve the problems they face in daily life by integrating the claim, evidence, and supports involved in the argumentation process into the engineering design process in the STEM education (Corlu, 2014; Demircioglu and Ucar, 2014; Fairweather, 2008). However, it is seen that studies using STEM and argumentation based education together are few. Thus, the study is thought to contribute to the literature with this aspect.

Purpose of the Study: The aim of this study; the Cunningham engineering design process based on the argumentation was determined as the preparation of an exemplary STEM activity in the scope of the "Force and Energy"unit of the seventh grade science course. 
Method: The study was conducted with 32 students (21 boys-11 girls) in seventh grade in an elementary school in Van province in the 2018-2019 academic year. The students were divided into six groups that were heterogeneous according to their academic achievement and gender. The implementation of the activity lasted four hours. The primary purpose of this activity is to make the students understand the concepts of the subject effectively by associating the related objectives of the topic with the problems of daily life and creating scenarios. The activities were implemented by starting with a scenario and integrating Toulmin's argumentation model components (claim, data, warrant, backing, qualifier, and refutation) into the Cunningham engineering design process (ask, imagine, plan, create, and improve).

\section{Application of the Activity:}

\section{My Floating Vehicle}

My floating vehicle activity was designed according to the objective (7.3.3.2. Design a tool to reduce the impact of air or water resistance) in the seventh grade science curriculum and lasted 4 hours. This topic is related to the forces in marine and air environments, the effect of friction force on objects, Marine, Air, and Land Engineering. At the beginning of the activity, some land and air vehicles was shown and their purpose of use has been explained In order to intensify the students' interest in the subject. Afterwards, activities were started by meeting with predetermined group members. The activity scenarios were distributed to the groups.

1. Ask (20 minutes): The groups tried to find solutions to the problem stated in the scenario and wrote the preliminary information and observations they collected for the solutions in the "data" section of the scenario texts at this stage. The groups made all the data in-group discussions and wrote the claims that best describe the problem situation. During this process, the teacher asked questions to the groups in order to encourage them to think. For example, "What information do you need for your vehicle?”, "How can this vehicle go faster? "How does the size of the vehicle affect its speed?", "How should the vehicle take precautions against adverse weather conditions?" and "What materials do you use to make the vehicle fit the intended purpose?” Thus, the students formed their claims by considering their answers to the questions.

2. Imagine (20 minutes): In this step, the students evaluated all the data they gathered by brainstorming both the teacher and each other and wrote the reasons for the problem solutions identified in the previous stage by integrating the possible solutions with 
different disciplines. Moreover, they supported these solution proposals/reasons by drawing.

3. Plan (20 minutes): At this stage, the students review the reasons they write considering the problem situation. The possible situations are indicated together with the reasons as warrant/backing and the most appropriate method of application is determined. Then, tools and equipment is found according to the criteria determined before (not dangerous, low cost, easily available) to implement the selected method.

4. Create (40 minutes): At this part, the groups form the product by using their hand skills to solve the problem. The teacher helps the students in using the tools (scissors, knives, etc.) that would be dangerous. S/he also encouraged the students to go beyond the designing process and to succeed in situation requiring hand skills, and not to give up. At the end of this stage, the students test whether their products work and they meet the specified criteria or not. Groups also present their products in class to evaluate the other groups.

5. Improve (40 minutes): At this stage, the groups discuss with other groups according to the criteria previously determined for the suitability of their designs. After the assessment, potential negative situations or corrections (Rebuttal) are identified and allowed to retest to improve their design. The teacher guided the creation of a democratic environment for these discussions to be fruitful.

Conclusion: The Floating Vehicle activity is an example of the usefulness of science and engineering applications in science classes. Teachers, who will apply this activity in their classrooms, will provide students with the experience of creating a new product with scientifically meaningful reasons by using the concepts of different disciplines for solving of the problem with the help of the design process of engineering based on the argumentation. This situation is thought to contribute to the development of skills expected from individuals in the 21st century. 